\title{
Postpartum Labial Adhesions
}

\author{
Dean A. Seebusen, MD, MPH, and J. Scott Earwood, MD
}

Background: Labial adhesions are common in young girls and menopausal women. Topical estrogen is the first line of therapy for these adhesions. Based on a systematic literature review, postpartum labial adhesions are uncommon in clinical practice. They are not painful but can prevent patients from resuming normal sexual activity. Topical estrogen therapy is an ineffective treatment option for adhesions in this setting. Surgical division under local anesthesia is usually effective.

Case: A 29-year-old women presented at 6 weeks after an uncomplicated vacuum-assisted delivery for a routine postpartum evaluation. Examination revealed a 5-mm labial adhesion connecting her left and right labia minora. Division under local anesthetic resulted in a complete recovery within 3 days.

Conclusion: Postpartum labial adhesions can usually be surgically divided under local anesthetic with complete and rapid recovery. (J Am Board Fam Med 2007;20:408-410.)

Labial adhesions are common in young girls and occasionally occur in elderly women. ${ }^{1}$ It is hypothesized that the relative hypoestrogenic states of these age groups predispose them to labial adhesions. ${ }^{2}$ Although surgical dissection is sometimes required, topical estrogen creams and gentle massage usually lead to successful breakdown of adhesions in these groups within a few weeks. ${ }^{3}$ Labial adhesions have also been described in reproductive age women secondary to female circumcision, lichen sclerosis, herpes simplex, diabetes, pemphigoid, and caustic vaginitis. ${ }^{3-7}$ Postpartum labial adhesions are rarely described in the medical literature.

\section{Case}

A 29-year-old woman, primigravida, underwent scheduled induction of labor at $412 / 7$ weeks. She received prostaglandin E2 for induction. An effective epidural was placed, and she progressed full to effacement and dilation. She pushed for $150 \mathrm{~min}-$ utes and, because of maternal exhaustion, required uncomplicated vacuum assistance. A second-degree

This article was externally peer reviewed.

Submitted 15 December 2006; revised 7 March 2007; accepted 9 March 2007.

From the Department of Family and Community Medicine, Eisenhower Army Medical Center, Augusta, GA.

Funding: none.

Conflict of interest: none.

Prior presentation: Uniformed Services Academy of Family Physicians Annual Scientific Assembly, Chicago, IL, March 2006.

Corresponding author: Dean A. Seehusen, MD, MPH, Eisenhower Army Medical Center, 212 Bainbridge Road, Evans, GA 30809. midline laceration was repaired in the usual fashion. In addition, superficial lacerations extending the entire length of both labia minora were noted with good hemostasis and were not repaired. She was instructed in standard perineal care, which included spreading the labia periodically and washing with water. The patient was discharged 48 hours after delivery with no complications and instructed to continue sitz baths and routine perineal hygiene at home.

At her scheduled 6-week postpartum examination, the patient stated that she and her husband had noticed that her vaginal area "did not look like it had healed right." They were unable to resume sexual activity secondary to inability to achieve penile insertion. She denied pain, vaginal discharge, or difficulty urinating. She was breastfeeding and taking no medications. A 5-mm tissue bridge connecting the right and left labia minora was observed (see Figure 1).

On the same day, the tissue bridge was injected with $1 \%$ lidocaine containing epinephrine and was divided with iris scissors. The patient tolerated the procedure well and was discharged from the hospital with instructions to separate the labia periodically to prevent reanastomosis. Three days later she was seen in follow-up. She had resumed sexual activity and was pain free. Examination revealed that her labia were completely healed (see Figure 2).

\section{Literature Review}

Labial adhesions in the postpartum setting are rare. A Medline literature review using the terms "labial 


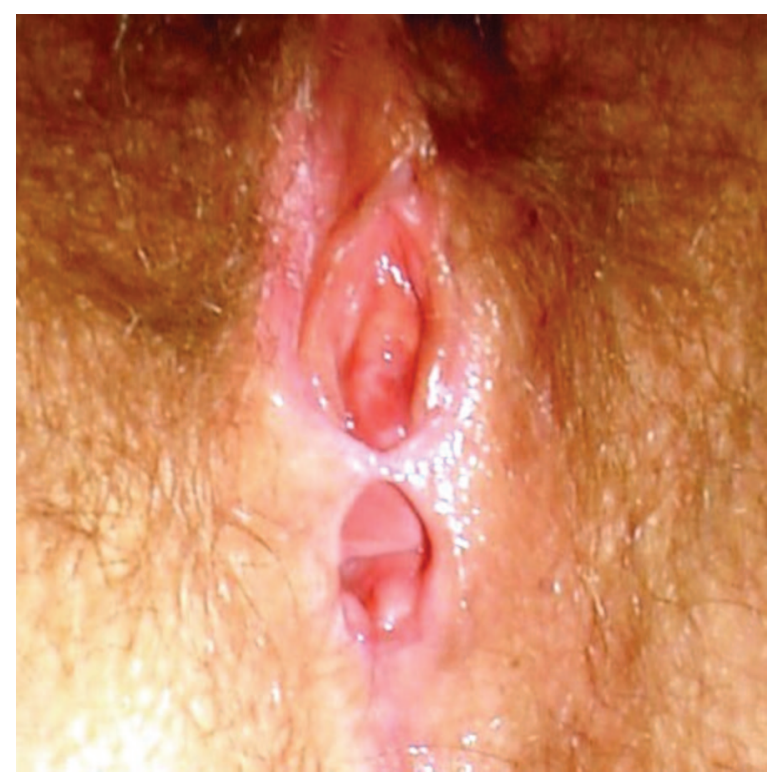

Figure 1. Labial adhesion before dissection.

adhesions" in combination with "postpartum" or "postnatal" was conducted. Relevant articles' references were reviewed for other possibly important literature. This search revealed only 9 previously reported cases of labial adhesions after vaginal delivery. Table 1 summarizes these cases.

Difficulty resuming sexual activity was the most commonly reported complaint. ${ }^{4,5,8-11}$ All but one of the previously reported cases of postpartum labial adhesions reported disruption of the vaginal mucosa. This ranged from "skid marks" to third-

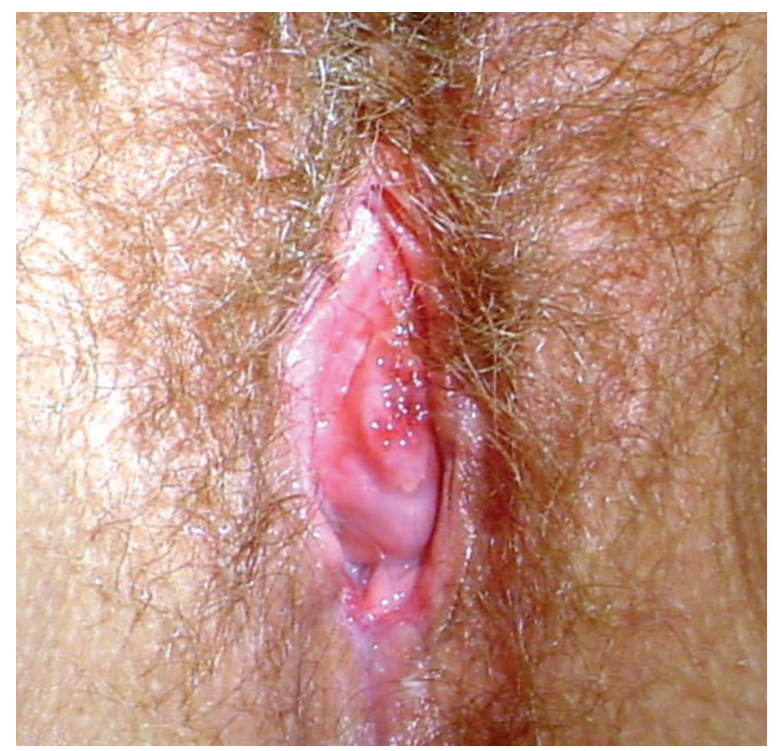

Figure 2. Well-healed labia 3 days later. degree perineal laceration. The remaining case did not specifically mention presence or absence of perineal trauma during delivery. In several of the cases, including the current case, superficial lacerations were left unrepaired. Superficial labial lacerations are often left unrepaired with good outcomes. Even larger vaginal wall lacerations will generally heal with similar outcomes if left unsutured as reported in some of the Midwifery literature. ${ }^{5}$ Lin et al theorized that significant perineal swelling may promote adhesion formation by mechanically pressing the labia together. ${ }^{3}$

\section{Discussion}

Optimal care of the perineum after delivery has been debated and researched, and practices have varied widely over the years and from institution to institution. ${ }^{12}$ Modern instructions for care of the postpartum perineum often include encouraging women to separate the labia with urination and periodically cleansing the perineum with a peribottle or sitz bath. These recommendations may be especially important for women with unrepaired labial lacerations to prevent the formation of tissue bridges from one labia to another. ${ }^{5,11}$

Topical estrogen cream is a common therapy for childhood or postmenopausal labial adhesions. These adhesions are very superficial and are the result of mild irritation of the vaginal mucus membranes and subsequent repair. Estrogen for several days to a few weeks, along with gentle massage, is often enough to disrupt adhesions in these groups and surgical treatment is reserved for refractory cases. ${ }^{3}$

A brief trial of estrogen cream was used unsuccessfully on 3 of the previously described postpartum labial adhesions. ${ }^{1,3,5}$ Several previous authors hypothesized that the relative hypoestrogenic state of the immediate postpartum period contributes to the formation of labial adhesions. ${ }^{1,3,8}$ However, this theory is not supported given that topical estrogen has failed to treat postpartum adhesions. The postpartum adhesions that have been described have all been tissue bridges or bands rather than thin membranes. The labia naturally come in close contact to one another when the legs are in the adducted position. When one or both labia have an open wound, growth of a tissue bridge across the labia can occur as a by-product of normal healing of the wound.

Most of the previously described adhesions were a few millimeters to several centimeters wide. Sur- 


\begin{tabular}{|c|c|c|c|c|}
\hline Author & Delivery & $\begin{array}{l}\text { Perineal Trauma with } \\
\text { Delivery }\end{array}$ & Initial Therapy & Definitive Therapy \\
\hline Shaver et al $(1986)^{1}$ & SVD & Vaginal sidewall & Topical estrogen & $\begin{array}{l}\text { Surgery with local } \\
\text { anesthetic }\end{array}$ \\
\hline $\begin{array}{l}\text { Davenport and Richardson } \\
(1986)^{8}\end{array}$ & SVD & $\begin{array}{l}\text { Episiotomy; massive vulvar } \\
\text { edema }\end{array}$ & $\begin{array}{l}\text { Surgery with general } \\
\text { anesthesia }\end{array}$ & $\begin{array}{l}\text { Surgery with general } \\
\text { anesthesia }\end{array}$ \\
\hline $\begin{array}{l}\text { Davenport and Richardson } \\
(1986)^{8}\end{array}$ & SVD & $\begin{array}{l}\text { Labial; massive vulvar } \\
\text { edema }\end{array}$ & $\begin{array}{l}\text { Surgery with local } \\
\text { anesthetic }\end{array}$ & $\begin{array}{l}\text { Surgery with local } \\
\text { anesthetic }\end{array}$ \\
\hline $\begin{array}{l}\text { Yoong and Alderman } \\
(1990)^{9}\end{array}$ & SVD & Superficial & $\begin{array}{l}\text { Surgery with general } \\
\text { anesthesia }\end{array}$ & $\begin{array}{l}\text { Surgery with general } \\
\text { anesthesia }\end{array}$ \\
\hline Greaves et al $(1998)^{4}$ & $\begin{array}{l}\text { Vacuum-assisted } \\
\text { delivery }\end{array}$ & $\begin{array}{l}\text { Episiotomy; ferric } \\
\text { subsulfate }\end{array}$ & $\begin{array}{l}\text { Surgery with general } \\
\text { anesthesia }\end{array}$ & $\begin{array}{l}\text { Surgery with general } \\
\text { anesthesia }\end{array}$ \\
\hline $\begin{array}{l}\text { Arkin and Chern-Hughes } \\
(2001)^{5}\end{array}$ & SVD & "Skid marks" & Topical estrogen & $\begin{array}{l}\text { Surgery with local } \\
\text { anesthetic }\end{array}$ \\
\hline Steele and Lowry $(2002)^{10}$ & SVD & Labial & Digital separation & $\begin{array}{l}\text { Surgery with general } \\
\text { anesthesia }\end{array}$ \\
\hline Lin et al $(2002)^{3}$ & SVD & Massive vulvar edema & Topical estrogen & $\begin{array}{l}\text { Amniotic membrane } \\
\text { graft }\end{array}$ \\
\hline Sharma et al $(2005)^{11}$ & SVD & Second degree & $\begin{array}{l}\text { Surgery with local } \\
\text { anesthetic }\end{array}$ & $\begin{array}{l}\text { Surgery with local } \\
\text { anesthetic }\end{array}$ \\
\hline $\begin{array}{l}\text { Seehusen and Earwood } \\
\text { (this paper) }\end{array}$ & $\begin{array}{l}\text { Vacuum-assisted } \\
\text { delivery }\end{array}$ & Second degree; labial & $\begin{array}{l}\text { Surgery with local } \\
\text { anesthetic }\end{array}$ & $\begin{array}{l}\text { Surgery with local } \\
\text { anesthetic }\end{array}$ \\
\hline
\end{tabular}

SVD, spontaneous vaginal delivery.

gical dissection was the definitive therapy in every reported case. This approach has the advantage that the procedure is brief and healing occurs rapidly versus the days to weeks required for topical estrogen to be effective. Injection of local agent provides adequate anesthesia to labial tissue, and using epinephrine helps decrease bleeding after division. Rarely, extensive adhesions may require general anesthesia.

\section{Conclusion}

Postpartum labial adhesions are rarely reported in the literature. Future research should attempt to establish the actual incidence of this condition, which may be much higher than the limited number of case reports suggests. Proper perineal care in the postpartum period may prevent labial adhesions from developing. Based on the currently available literature, topical estrogen therapy cannot be recommended. Surgical dissection done under local anesthesia should be attempted as first line therapy for postpartum labial adhesions.

\section{References}

1. Shaver D, Ling F, Muram D. Labial adhesions in a postpartum patient. Obstet Gynecol 1986;68:S24-5.

2. Webster J, Williams G. Adhesions of the labia minora. Br J Urol 1996;78(1):146-7.
3. Lin Y, Hwang J, Huang L, Chou C. Amniotic membrane grafting to treat refractory labial adhesions postpartum. J Reprod Med 2002;47:235-7.

4. Greaves P, Elder R, Copas P. Labial adhesions as a result of caustic vaginitis in a postpartum patient. J Gynecol Surg 1998;14:129-31.

5. Arkin A, Chern-Hughes B. Case report: labial fusion postpartum and clinical management of labial lacerations. J Midwifery Women Health 2001;47(4): 290-2.

6. Kato K, Kondo A, Takita T, Mitsuya H. Labial adhesions in a diabetic woman. Urol Int 1986;41(6): 455-6.

7. Ikegaya H, Kato A, Matsushima H, Takai K, Hosaka Y, Kitamura T. A case of cicatricial pemphigoid producing severe dysuria due to labial adhesion. BJU Int 1999;83(6):735-6.

8. Davenport D, Richardson D. Labial adhesions secondary to postpartum vulvar edema. J Reprod Med 1986;31(6):523-4.

9. Yoong A, Alderman B. A large labial adhesion following normal delivery. Acta Obstet Gynecol Scand 1990;69:443.

10. Steele E, Lowry D. Labial adhesions following normal delivery. J Obstet Gynaecol 2002;22(5):555.

11. Sharma B, Arora R, Preston J. Postpartum labial adhesions following normal vaginal delivery. J Obstet Gynaecol 2005;25(2):215.

12. Rhode M, Barger M. Perineal care: then and now. J Nurse Midwifery 1990;35(4):220-30. 